\title{
Prevalence of Toxins and Antimicrobial Resistance among $E$ coli Isolated from Meat
}

\author{
Shaymaa H. Abdel-Rhman', Sara M. Khalifa², Khaled H. Abd El Galil1, Rasha M. Barwa1* \\ ${ }^{1}$ Microbiology and Immunology Department, Faculty of Pharmacy, Mansoura University, Mansoura, Egypt \\ ${ }^{2}$ Ministry of Health, Mansoura, Egypt \\ Email: rasha2000@gmail.com
}

Received 15 September 2015; accepted 18 October 2015; published 21 October 2015

Copyright (C) 2015 by authors and Scientific Research Publishing Inc.

This work is licensed under the Creative Commons Attribution International License (CC BY).

http://creativecommons.org/licenses/by/4.0/

(c) () D Den Access

\begin{abstract}
Aim: The present study aims to evaluate the occurrence and characterize $E$. coli in meat and meat products marketed in Egypt based on their antimicrobial-resistance pattern and production of enterotoxins. Methods: A total of 250 meat samples, categorized as 80 fresh beef, 85 ground beef and 85 beef burger purchased from supermarkets and butchers' shops were used for isolation of $E$. coli. All isolates were screened for antimicrobial susceptibility. Plasmid profile analyses were done. Polymerase chain reactions were performed for detection of enterotoxin-encoding genes (astA, eaeA, stx1 and stx2). Results: Twenty-five samples were isolated and identified as E. coli. 14 isolates were multidrug resistant. Plasmids isolation from all isolates revealed that $76 \%$ of these isolates harbored plasmids. astA gene was amplified in 7 isolates $(28 \%)$. Eight $(32 \%)$ isolates harbored eaeA gene. However, none of the isolates harbored stx 1 or stx 2 genes. Analysis of multiple drug resistant isolates revealed a significant relation between multiple drug resistance and both $a s t A$ and $e a e A$. Conclusion: The study confirmed the prevalence of enterotoxin genes (ast $A$ and $e a e A$ ) in $E$. coli isolated from meat product and the association between the presence of these genes and multiple drug resistant phenomena.
\end{abstract}

\section{Keywords}

Enterotoxin, E. coli, Antimicrobial Resistance, Meat Products

\section{Introduction}

Meat is a nutritive, protein-rich food which is very perishable and has a short shelf-life unless preservation methods are applied [1]. Shelf life and keeping of the meat quality are affected by a number of interrelated factors including holding temperature, which can cause deleterious changes in the quality attributes of meat. Spoil-

*Corresponding author. 
age due to microbial growth is the most important factor in relation to maintaining quality of meat [2].

In most developing countries, fresh meat constitutes a considerable proportion of meat intake [1]. To avoid spoilage, it is either eaten cooked or processed into other forms. The main causative factor of such spoilage is associated with unavailability of necessary storage facilities and suitable ambient temperature that is usually prevalent in developing countries that are in tropical regions [3].

The Gram-negative bacterium, Escherichia coli is a major member of the bacterial microbiota of the environment and in the feces of many species of mammals and birds. E. coli constitutes $14 \%$ of all cultivable bacteria of the colon, and up to $10^{10} \mathrm{CFU}$ E. coli can be detected in $1 \mathrm{~g}$ of feces [4].

Commensal E. coli strains are very important since they maintain the physiological milieu of the gut and support digestion as well as protect against enteric pathogens. Other $E$. coli strains harbor and express virulence genes that cause serious outbreaks of diarrhea (diarrheagenic E. coli) [5]. These virulence genes are often located on transmissible genetic elements and therefore can be transmitted to receptive E. coli recipient strains [6]. Cattle are considered the main reservoir of diarrheagenic $E$. coli especially enterohemorrhagic $E$. coli and an important source for contamination of human food supply.

E. coli can be transferred into meat products through various routes. The animal feces can be transferred on the carcass and hides; the equipment can be contaminated; personnel might not follow proper hygienic practices; airborne contamination, and rodents, insects, and other animals are all possible sources [7].

In several epidemiological studies, five categories of $E$. coli have been well associated with diarrhea. These categories are enteropathogenic E. coli (EPEC), enteroaggregative E. coli (EAEC), enterotoxigenic E. coli (ETEC), enteroinvasive E. coli (EIEC), and enterohemorrhagic E. coli (EHEC) which are mostly regarded as shiga toxin-producing E. coli (STEC) [8].

The virulence mechanisms that characterize the different categories of $E$. coli are genetically encoded by chromosomal, plasmid, and bacteriophage DNAs and are represented by various virulent genes. These genes include eae (attaching and effacing lesions), ipaH (enteroinvasive mechanism), the gene encoding enteroaggregative adherence, $b f p A$ (localized adherence), the genes encoding heat-labile toxin (LT) and heat-stable toxin (ST), and stx 1 and stx2 (Shiga toxins) [9].

The misuse of antibiotics has led to the emergence of antimicrobial resistance in multiple bacterial isolates [10]. Foods contaminated with antibiotic resistant bacteria could be a serious threat to public health because there is a great possibility that genes encoding antibiotic resistance determinants that are carried on mobile genetic elements may be transferred to other bacteria of human clinical significance [11]. Development of such resistant bacteria may establish a problem in treatment of acute infections in man and animals. The antimicrobial agents have an important value for devising therapeutic measures against bacterial infections. However, the frequency of R-factor and its transmissibility in E. coli is a serious problem in treating such infections. Thus, with great expansion of sheep meat industry, E. coli is considered a problem of economic concern to all stages of meat industry-from production to marketing to consumer health significance, to the clinicians-due to emergence of multiple drug resistant bacteria, and to veterinarians due to reservoirs of infection.

The present study aims to evaluate the occurrence and characterize E. coli in meat and meat products marketed in Egypt. This characterization was based on the ability of the isolates to produce enterotoxins, on the antibiotic susceptibilities in order to determine the presence of multiple drug resistant isolates. Furthermore, the relationship between the different origins of the isolates and the ability of these isolates to produce enterotoxins and their resistant pattern was also evaluated.

\section{Materials and Methods}

\subsection{Meat Sample Collection}

A total of 250 meat samples, categorized as 80 fresh beef samples besides 85 ground beef and 85 beef burger purchased from supermarkets and butchers' shops distributed in Egypt. Each individual meat sample was aseptically packaged into a polyethylene bag then marked and transferred in an icebox to the laboratory of Food Hygiene and Control Department, Faculty of Veterinary Medicine, Mansoura University, wherein the bacterial isolation were done. Samples were stored at $4^{\circ} \mathrm{C}$ till further analysis.

\subsection{Isolation of $E$. coli}

Twenty five grams from each meat sample were separately blended for 1 min in a sterile food blender, with 225 
$\mathrm{ml}$ of sterile tryptone soya broth. The resultant suspension was then incubated at $37^{\circ} \mathrm{C}$ for $18-20 \mathrm{~h}$. For isolation of E. coli, MacConkey agar (MCA) and Eosin-methylene blue (EMB) agar were used as differential and selective medium respectively, all Oxoid products. The MCA and EMB agar were incubated at $37^{\circ} \mathrm{C}$ for $24 \mathrm{hr}$. Then each morphological consistent colony was purified and subjected to biochemical characterization according to Barrow and Felthman (1993) [12]. All the purified isolates were maintained in glycerol $30 \%$ at $-80^{\circ} \mathrm{C}$.

\subsection{Antimicrobial Susceptibility Testing}

Susceptibility to antimicrobials was determined by the disc-diffusion method using Mueller-Hinton agar (Becton, Dickinson and company, USA) according to the Clinical and Laboratory Standards Institute (CLSI) 2011 [13]. Twelve antimicrobial discs were used including: ampicillin (10 $\mu \mathrm{g})$, amoxicillin/clavulanic acid (30 $\mu \mathrm{g})$, ceftriaxone $(30 \mu \mathrm{g})$, ceftazidime (30 $\mu \mathrm{g})$, cefipeme (30 $\mu \mathrm{g})$, imipenem $(10 \mu \mathrm{g})$, erythromycin $(15 \mu \mathrm{g})$, gentamicin (10 $\mu \mathrm{g})$, tobramycin $(10 \mu \mathrm{g})$, ciprofloxacin $(5 \mu \mathrm{g})$, norfloxacin $(10 \mu \mathrm{g})$ and chloramphenicol $(30 \mu \mathrm{g})$. All discs were supplied from Oxoid products, UK.

\subsection{Molecular Studies}

\subsubsection{Preparation of Plasmid DNA Content of the Isolated Strains Using DNA-Spin ${ }^{\mathrm{TM}}$}

Plasmid DNA Purification Kit (iNtRON Biotechnology, Inc:)

The plasmid contents of all E. coli isolates were prepared using DNA-spin ${ }^{\mathrm{TM}}$ plasmid DNA Purification kit cat. No. 17091 ISO9001 (iNtRON Biotechnology, Inc.), according to manufacturer instructions. Plasmid DNA was visualized by electrophoresis on horizontal gels containing $0.8 \%$ agarose stained with ethidium bromide and illuminated under UV translluminator and photographed.

\subsubsection{Isolation of Chromosomal DNA from Bacterial Plate Cultures Using I-Genomic BYF DNA Extraction Mini Kit (iNtRON Biotecnology, Inc.)}

The genomic DNA of all E. coli isolates was prepared using i-genomic BYF DNA Extraction Mini kit (Cat. No. 17361, iNtRON Biotecnology, Inc.), according to manufacturer instructions. Genomic DNA was visualized by electrophoresis on horizontal gels containing $0.8 \%$ agarose stained with ethidium bromide and illuminated under UV translluminator and photographed.

\subsubsection{PCR Experiments}

PCR experiments were done according to El Naggar et al., 2011 [14]. The genomic DNA from every isolates of E. coli was used as template for PCR experiments. The sequences of the oligonucleotides primers used in this study are shown in Table 1. The PCR reaction was: $12.5 \mu \mathrm{l}$ Dream Taq ${ }^{\mathrm{TM}}$ Green PCR Master Mix (2X) (Dream Taq ${ }^{\mathrm{TM}}$ DNA polymerase, optimized Dream Taq ${ }^{\mathrm{TM}}$ Green buffer, $\mathrm{MgCl}_{2}$, dNTPS), $1 \mu$ of forward primer $(10 \mu \mathrm{M})$, $1 \mu \mathrm{l}$ of reverse primer $(10 \mu \mathrm{M}), 1 \mu \mathrm{l}$ of the DNA template and $9.5 \mu \mathrm{l}$ of nuclease free water were added for a total $25 \mu \mathrm{l}$ per reaction. The PCR conditions were started with initial denaturation step at $95^{\circ} \mathrm{C}$ for $5 \mathrm{~min}$, followed

Table 1. Oligonucleotide primers used to amplify the tested genes.

\begin{tabular}{|c|c|c|c|c|}
\hline Gene name & & Sequence & Annealing temperature & References \\
\hline \multirow{2}{*}{$s t x 1$} & Fw & 5'... ATAAATCGCCATTCGTTGACTAC & \multirow{2}{*}{$58^{\circ} \mathrm{C}$} & \multirow{2}{*}{ This study } \\
\hline & $\mathrm{Rv}$ & 5'...AGAACGCCCACTGAGATCATC & & \\
\hline \multirow{2}{*}{$s t x 2$} & Fw & 5'...GGCACTGTCTGAAACTGCTCC & \multirow{2}{*}{$58^{\circ} \mathrm{C}$} & \multirow{2}{*}{ This study } \\
\hline & $\mathrm{Rv}$ & 5'...TCGCCAGTTATCTGACATTCTG & & \\
\hline \multirow[b]{2}{*}{ eaeA } & Fw & 5'... GACCCGGCACAAGCATAAGC & \multirow[b]{2}{*}{$60^{\circ} \mathrm{C}$} & \multirow[b]{2}{*}{ This study } \\
\hline & $\mathrm{Rv}$ & 5'...CCACCTGCAGCAACAAGAGG & & \\
\hline \multirow{2}{*}{ ast $A$} & Fw & 5'... GCCATCAACACAGTATATCC & \multirow{2}{*}{$58^{\circ} \mathrm{C}$} & \multirow{2}{*}{ This study } \\
\hline & $\mathrm{Rv}$ & 5'... GAGTGACGGCTTTGTAGTCC & & \\
\hline
\end{tabular}

Fw: forward; Rv: reverse. 
by 40 cycles of denaturation at $95^{\circ} \mathrm{C}$ for 30 second (s), annealing temperatures for each primer were listed in Table 1 for $40 \mathrm{~s}$, and extention at $72^{\circ} \mathrm{C}$ for $1 \mathrm{~min}$ and final extention at $72^{\circ} \mathrm{C}$ for $5 \mathrm{~min}$. The generated amplicons were visualized by electrophoresis on $1.2 \%$ agarose gel stained with ethidium bromide and illuminated under UV translluminator and photographed.

\subsection{Statistical Analysis}

Statistical analysis was performed using the $\chi^{2}$ test. Data was analyzed using the GraphPad Instate software package (version 3.05) according to the TukeyeKramer multiple-comparison test at a $p<0.05$ for significance.

\section{Results}

\subsection{Incidence of E. coli in Meat Types}

A total of 25 E. coli were isolated and purified from 250 meat samples. The prevalence of E. coli isolates in tested samples of fresh beef, ground beef, and beef burger was 4,7 and 14 respectively.

\subsection{Antimicrobial Susceptibility of the Tested Organisms}

In term of overall response of $E$. coli isolates to tested antimicrobials, ampicillin, amoxicillin/clavulanic acid, ceftriaxone and ceftazidime showed the least overall potency (4\% - 24\%). For gentamicin, ciprofloxacin, norfloxacin, chloramphenicol and erythromycin; the overall potency against $E$. coli isolates was (48\% - 64\%). While for imipenem, cefepime and tobramycin; the overall potency was around ( $80 \%-100 \%)$ as indicated in Table 2. Multiple drug resistance (MDR) was demonstrated in 14 isolates (56\%), showing simultaneous resistant to more than two classes of antibiotics).

The relation between the percentage of resistant isolates and the number of the antibiotics were shown in Figure 1. Out of $25 \mathrm{E}$. coli isolates, 15 isolate (60\%) were resistant to 5 or more antibiotic but no isolate were resistant to all the 12 antimicrobials. In addition, no isolate exhibited complete sensitivity to all antimicrobials.

\subsection{Plasmid Profile Analysis}

The plasmid DNA profile Figure 2 illustrated that fifteen isolates had similar plasmid band patterns, possessing a single plasmid with a size (23 kbp). Additionally, three isolates harbored two plasmids for each with sizes (23 $\mathrm{kbp}$ and $9.4 \mathrm{kbp}$ ). Another three isolates harbored 3 plasmid bands with sizes (23 kbp, $9.4 \mathrm{kbp}$ and $6.5 \mathrm{kbp}$ ) for isolate No. 2; sizes (23 kbp, 9.4 kbp and nearly 5.4 kb) for isolate No.6 and sizes (23 kbp, 9.4 kbp and 2 kbp) for isolate No. 8. On the other hand, four isolates (No. 4, 12, 14 and 25) were devoid of plasmids.

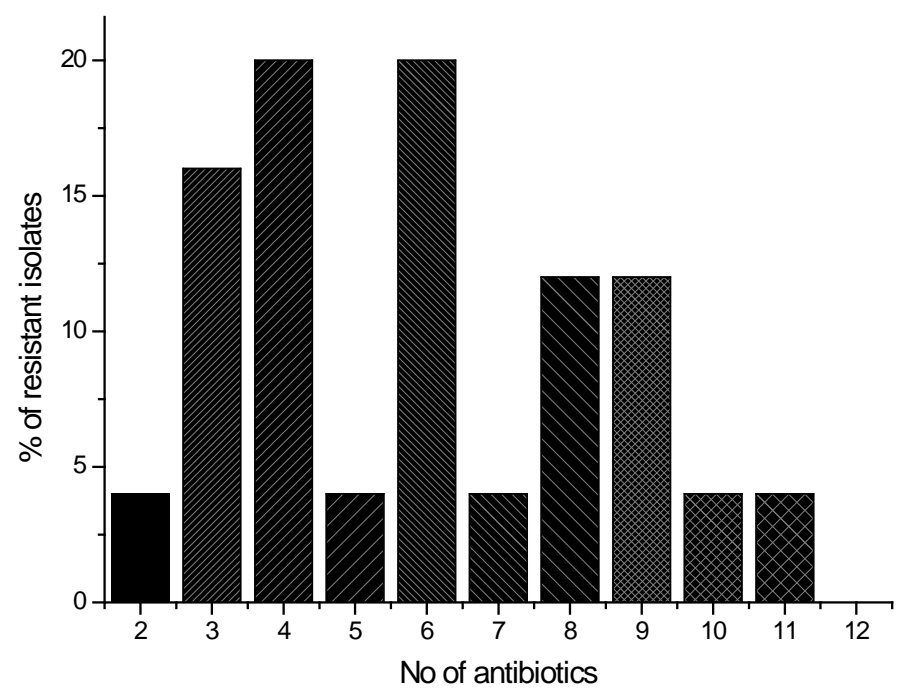

Figure 1. The relation between the percentage of resistant isolates and the number of the antibiotics. 


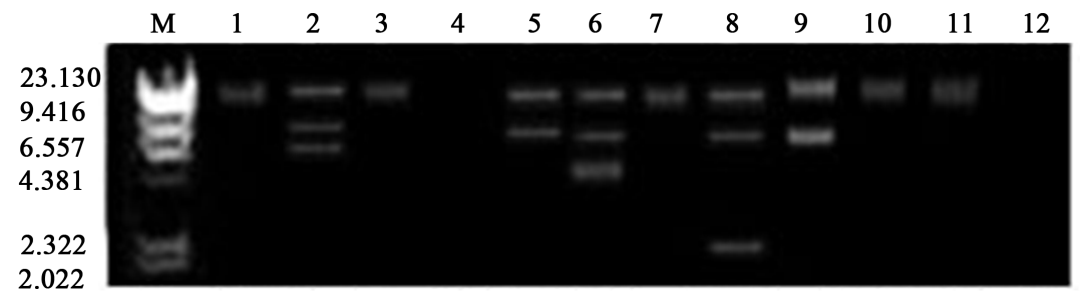

(a)

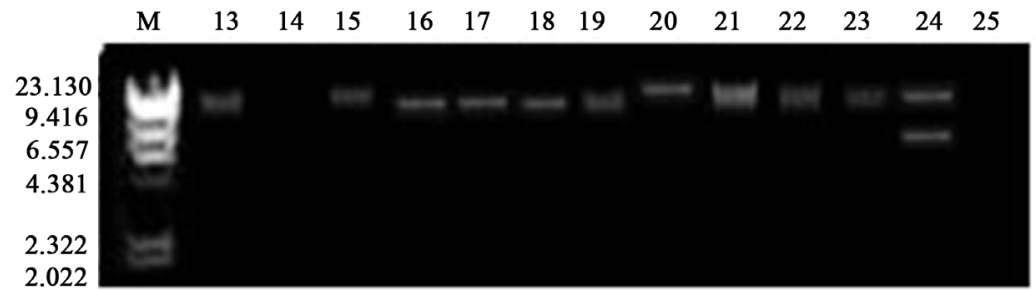

(b)

Figure 2. Plasmid DNA profiles of $E$. coli isolates. (a) Lanes 1-12 represent isolates No. 1, 2, 3, 4, 5, 6, 7, 8, 9, 10, 11, 12 respectively. Lane M: $\lambda$ Hind III marker; (b) Lanes 13-25 represent isolates No. $13,14,15,16,17,18,19,20,21,22,23,24,25$ respectively. Lane M: $\lambda$ Hind III marker.

Table 2. Antimicrobial susceptibility of $E$. coli isolates.

\begin{tabular}{cccc}
\hline Antimicrobial agents & & No. of $\boldsymbol{E}$. coli isolates $(\mathbf{n}=\mathbf{2 5})$ & $\mathbf{S}$ \\
\cline { 2 - 3 } Ampicillin & $\mathbf{R}$ & $\mathbf{I}$ & 1 \\
Amoxicillin/clavulanic & 24 & - & 2 \\
Ceftriaxone & 23 & - & 3 \\
Ceftazidime & 22 & - & 2 \\
Cefepime & 19 & 4 & 23 \\
Imipenem & 1 & - & 25 \\
Erythromycin & - & 1 & 14 \\
Gentamicin & 10 & - & 12 \\
Tobramycin & 13 & 3 & 8 \\
Ciprofloxacin & 5 & 5 & 10 \\
Norfloxacin & 12 & 5 & 9 \\
Chloramphenicol & 10 & 7 & 9 \\
\hline
\end{tabular}

S, Sensitive; I, Intermediate; R, Resistant.

\subsection{Polymerase Chain Reaction for Amplification of Enterotoxin-Encoding Genes on Genomic DNA of $E$. coli}

PCR of heat-stable enterotoxin gene (astA) reveled that it was harbored by chromosomal DNA of seven isolates (28\%) with amplicon size of 390 bp Figure 3 . With regard to st 1 and stx2 genes, none of the E. coli isolates possessed these genes. However, eaeA gene was presented in 8 isolates (25\%) with size 550 bp Figure 4 . The distribution of eaeA and astA gene among E. coli isolates with regard to their isolation source was shown in Table 3. Estimation of MDR phenomena among $E$. coli isolates revealed that $100 \%$ of astA harbored $E$. coli isolates and $100 \%$ of eaeA harbored $E$. coli isolates were MDR Figure 5. There was significant relation between the presence of both $a s t A$ and $e a e A$ and multiple drug resistance phenomena $(p<0.0001)$. 


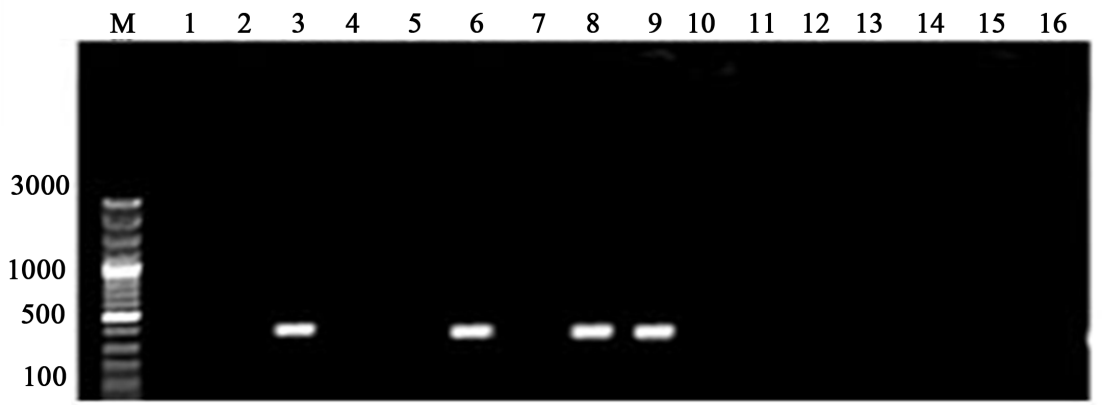

(a)

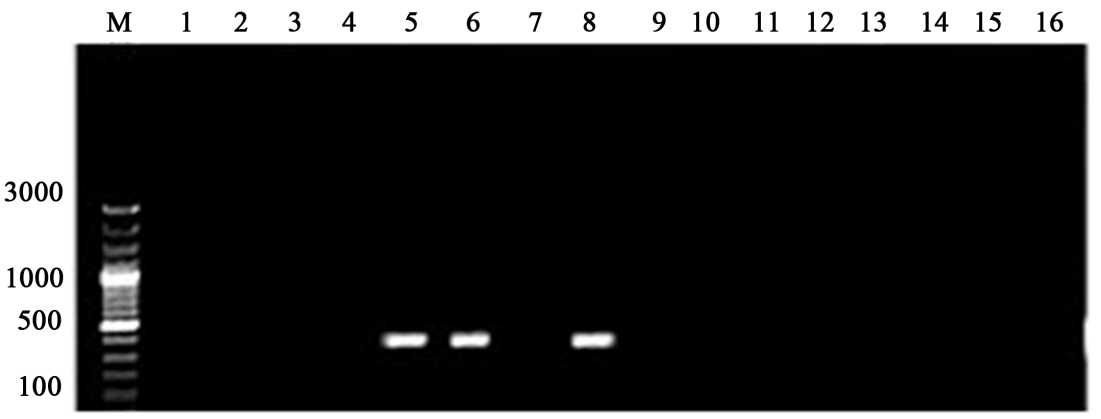

(b)

Figure 3. Agarose gel electrophoresis of astA gene amplicone from genomic DNA of E. coli. Lane M was 100 bp plus DNA ladder. (a) Lanes from 1 to 16 were amplicones from isolates No. 1, 2, 3, 4, 5, 6, $7,8,9,10,11,12,13,14,15$ and 16 respectively; (b) Lanes from 1 to 9 were amplicones from isolates No. $17,18,19,20,21,22,23,24$ and 25 respectively. Lane 10 was negative control.

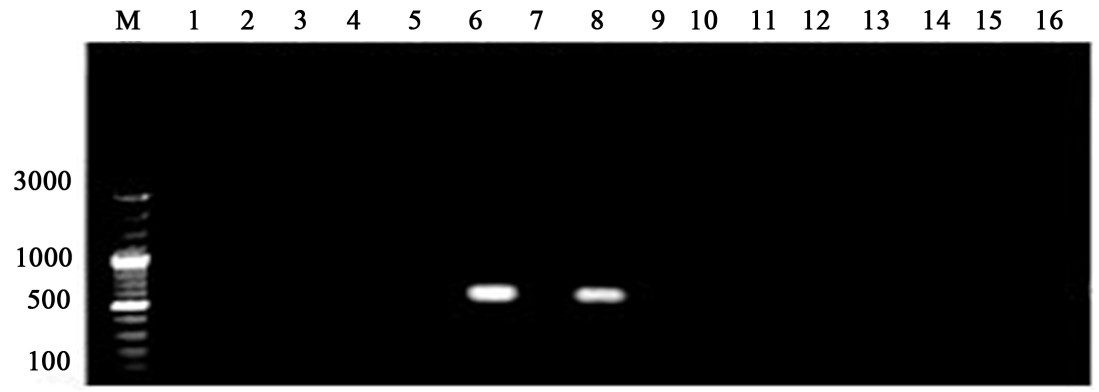

(a)

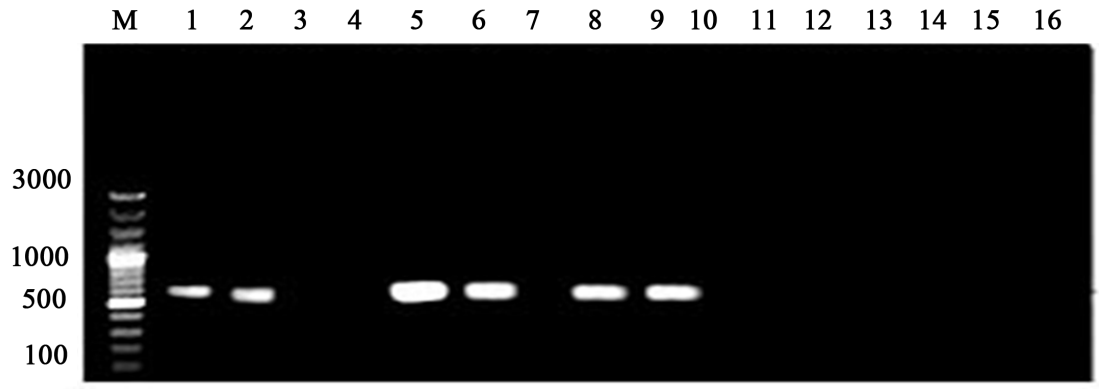

(b)

Figure 4. Agarose gel electrophoresis of eaeA gene amplicone from genomic DNA of E. coli. Lane M was 100 bp plus DNA ladder. (a) Lanes from 1 to 16 were amplicones from isolates No. 1, 2, 3, 4, 5, 6, 7, 8, 9, 10, 11, 12, 13, 14, 15 and 16 respectively; (b) Lanes from 1 to 9 were amplicones isolates No. $17,18,19,20,21,22,23,24$ and 25 respectively. Lane 10 was negative control. 


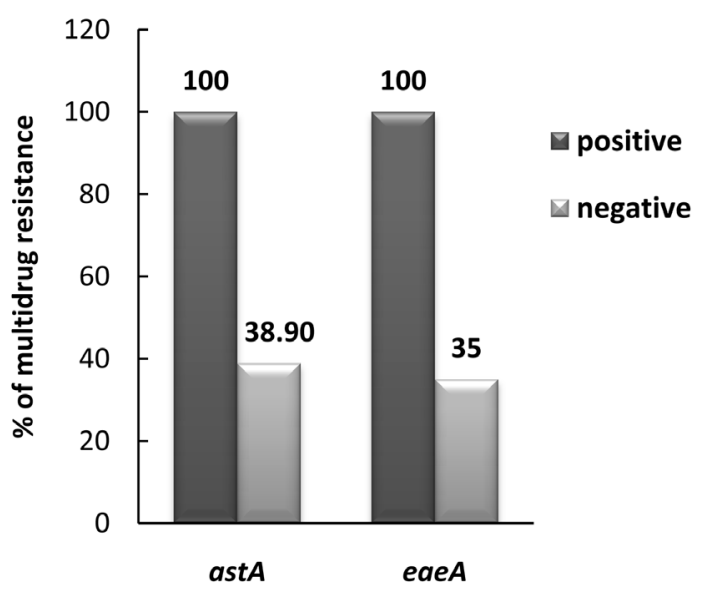

Figure 5. Correlation between the presence of ast $A$ and eaeA gene and multiple drug resistance.

Table 3. Prevalence of enterotoxins ast $A$ and eaeA in E. coli isolates from different meat samples.

\begin{tabular}{|c|c|c|c|c|}
\hline \multirow{2}{*}{ Gene name } & \multicolumn{3}{|c|}{ Isolation source } & \multirow{2}{*}{ Total $(\mathrm{n}=25$} \\
\hline & Fresh beef from butcher's shop $(n=3)$ & Ground beef $(n=7)$ & Beef burger $(n=15)$ & \\
\hline eaeA & $1(33.3 \%)$ & $1(14.28 \%)$ & $1(6.66 \%)$ & $3(12 \%)$ \\
\hline astA & $2(66.6 \%)$ & $-(0 \%)$ & $-(0 \%)$ & $2(8 \%)$ \\
\hline$e a e A+a s t A$ & $-(0 \%)$ & $2(28.5 \%)$ & $3(20 \%)$ & $5(20 \%)$ \\
\hline
\end{tabular}

\section{Discussion}

The prevalence of $E$. coli isolates in tested samples of fresh beef, ground beef, and beef burger was $16 \%$, $28 \%$ and $56 \%$ respectively. It is noteworthy that, amongst the meat products tested, fresh beef was considered the lowest contaminated product with $E$. coli, followed by ground beef whilst beef burger was the highly contaminated product which indicated that more than half of the tested samples positive for $E$. coli were isolated from beef burger. The relatively higher incidence of $E$. coli strains in tested beef burger and ground beef samples may be attributed to the fact that these two products are manufactured from imported frozen meat which undergo subsequent processing as grinding and addition of non-meat ingredients, along with different hygienic measures and sanitation levels during processing, packaging, handling, distribution and storage [15].

Food is a leading factor for the transfer of antibiotic resistances. This transfer can occur by means of antibiotic residues in food, through the transfer of resistant food-borne pathogens or due to the ingestion of resistant strains of the original food microflora and resistance transfer to pathogenic microorganisms [16]. In addition to the misuse of antibiotics, the rate of resistance to these antimicrobial agents in developing countries is high which attributed to the use of these drugs in gastroenteritis and self medication which are often the causes of resistance. While the causes of resistance in developed countries may be due to, the use of these antibiotics in animal feeds and by traveling to developing countries [17].

Resistance pattern of the tested isolates were determined according to CLSI, 2011 [13] using disc diffusion method. The results showed significant multiple resistances. As shown in Table 2 most of E. coli isolates showed high resistance to ampicillin and amoxicillin-clavulanic acid $(96 \%, 92 \%)$ respectively. The results showed that the resistance of E. coli isolates to ciprofloxacin, norfloxacin and chloramphenicol were (48\%), $(40 \%)$ and $(36 \%)$ respectively. Ten isolates $(40 \%)$ showed resistance to erythromycin. For aminoglycosides antibiotics, it was found that thirteen isolates $(52 \%)$ were resistant to gentamicin, while for tobramycin only five isolates $(20 \%)$ were resistant. On the other hand $(100 \%)$ of isolates were sensitive to imipenem.

Zhao et al. (2009) [18] reported that resistance rate of $E$. coli isolates to ampicillin was greater than $90 \%$. Motina and Yadava (2005) [19] observed that $41.37 \%$ E. coli isolates were resistant to norfloxacin. Our results were in accordance with a study conducted in Egypt by El Naggar et al. [14] which showed that $96.7 \%$ of E. coli isolates were resistant to cefepime, $40 \%$ to chloramphenicol, $53.3 \%$ to gentamicin, $60 \%$ to ciprofloxacin; while 
all isolates were sensitive to imipenem. While a study in Spain conducted by Álvarez-Fernández et al., 2013 [20] showing the rates of resistance of $E$. coli isolates was $(75.0 \%)$ to ampicillin, (73.3\%) ciprofloxacin and (45\%) to amoxicillin-clavulanic acid.

According to Figure 1, 36\% of the isolates were resistant to seven or more antimicrobial. A lower percent (26.6 \%) was found in the study of Yadav et al., 2007 [21].

On the overall isolates; $56 \%$ of them showed multidrug resistance MDR. The MDR isolates had a general drug resistance pattern of AMP-AMC-CRO-CAZ. A lower percent of multiple drug resistance was found in the study of Suojala et al., 2011 [22] where only $20.1 \%$ of the E. coli isolates were reported as MDR. Van et al., 2008 [23] has revealed that $E$. coli in raw foods is a significant reservoir of resistance and virulence genes. Multiresistance observed in beef was (15\%).

Multidrug-resistant E. coli is an emerging clinical challenge in domestic species. Treatment options in many cases are limited [24]. Our findings demonstrate significant MDR E. coli isolated from meat (56\%).The antibiogram phenotype of $E$. coli isolates shows that treatment options are limited. It seems that imipenem and cefepime can serve as a medication of choice for treatment infections caused by multidrug resistant $E$. coli. However, it should be noted that imipenem has some drawbacks with fluid restricted patients and unlimited use of imipenem and cefepime can gradually lead to rising antibiotic resistance.

MDR in microorganisms was known to develop as a result of antibiotics misuse or acquisition of transferrable plasmids [25]. In this study, plasmids isolation from all isolates revealed that $84 \%$ of E. coli isolates harbored plasmids (Figure 2). Of them 60\% exhibited similar plasmid band size $23 \mathrm{kbp}, 12 \%$ have 2 plasmids with sizes (23 kbp and $9.4 \mathrm{kbp}$ ) and 12\% have 3 plasmids with sizes (23 kbp, $9.4 \mathrm{kbp}$ ) and the third plasmid with size of (6.5, nearly 5.4 or $2 \mathrm{kbp}$ ). While $16 \%$ have no plasmids. Mobile plasmids are usually less than $10 \mathrm{~kb}$ in size while conjugative ones are sized between 20 and $30 \mathrm{~kb}$ [26]. Conversely the heavy weight plasmids (23 kbp) detected in our MDR strains of $E$. coli may be conjugative therefore their resistance determinants may have been acquired by horizontal transfer from species, while the other light plasmids (2, 5.4, 6.55 and 9.4) are mobile plasmids.

Plasmid fingerprinting was the first molecular method has been used for demonstrating the similarity of clinical isolates of bacteria in epidemiological studies. Isolates from the same strain contain the same number of plasmids with the same molecular weights and generally the same phenotype. Origin of isolates was indicated more accurately by plasmid fingerprinting [27]. In fact, plasmid profiles of the isolates are generally a useful tool for obtaining knowledge about enterotoxin production, resistance to antimicrobials and transfer of a plasmid among closely related isolates from different sources. Plasmid profile is one of several useful methods for determining the relatedness and unrelatedness of bacterial strains that contain plasmid DNA.

PCR analysis for enterotoxin genes ( $s t x 1, s t x 2$, ast $A$ and $e a e A)$ revealed that enteroaggregative heat-stable enterotoxin gene (astA) is harbored by $28 \%$ E. coli isolates with band size 390 bp (Figure 3). Of these isolates; $42.5 \%$ were isolated from beef burger (No.8, 9 and 24), 28.5\% isolated from ground beef (No. 6 and 22) and $28.5 \%$ isolated from fresh beef (No. 3, 21). Similar results achieved by Sousa and Dubreuil, 2001 [28] where the 358 bacterial strains studied using PCR showed that the astA gene was present $71 \mathrm{E}$. coli isolates (32.6\%). Zahfer, 2013 [29] found that (astA) gene was predominant over the other detected enterotoxin genes; A higher percent was noticed in the study of Vu Khac et al., 2006 [30] where 64\% of the isolates harbor astA gene.

With regard to st $x 1$ and st $x 2$ genes, none of the E. coli isolates possessed these genes. Our results are in accordance with Shabana et al. (2013) [31] where all E. coli isolates were negative for the presence of shigatoxin2 (stx2). Also these results are in accordance with Van et al. (2008) [23] where in this case, the stx1 and $s t \times 2$ virulence genes associated with the STEC pathotype were not detected.

Regarding eaeA gene, it is harbored by 8 strains of $E$. coli isolates (32\%) with band size 550 bp (Figure 4). Among them, 4 isolates $(50 \%)$ were beef burger isolates (No. 2, 8, 9, and 24), three isolates (37.5\%) were ground beef isolates (No. 5, 6 and 22), only one fresh beef isolate (12.5\%). A lower percent were introduced by Mohmmed et al. (2014) [32] where PCR was performed for categorizing diarrheagenic E. coli other than STEC. It was found that $12 \%$ were designated as EPEC based on amplification of eaeA gene. Gallien et al. (1999) [33] reported different results were found for strains isolated from minced meat in Germany. None of the 36 further characterized strains harbored the eaeA gene; however, $25 \%$ ast $A$ positive.

The correlation between the presence of enterotoxin genes and MDR phenomena among E. coli isolates was studied (Figure 5). It was found that $100 \%$ of astA harbored $E$. coli isolates were MDR while only $38.9 \%$ of astA negative isolates were multidrug resistant. With regard to eaeA gene $100 \%$ of eaeA harbored $E$. coli isolates 
were multidrug resistant while only $35 \%$ of eaeA negative isolates were multidrug resistant. Statistical analysis revealed that there was significant relation between the presence of both ast $A$ and eaeA and multiple drug resistance phenomena $(p<0.0001)$. Multidrug-resistant $E$. coli is an emerging clinical challenge in domestic species. Our results demonstrate the high prevalence of enteroaggregative heat-stable enterotoxin (astA) and intimin (eaeA) gene in E. coli isolated from meat product which may be involved in food poisoning. In the study of Mohammad, 2012 [9] the presence of astA by was investigated PCR, (46.7\%) of the EAEC isolates harbored the astA gene and multidrug resistance was observed in high levels.

\section{Conclusions}

In conclusion our investigation highlights that the presence of enterotoxigenic and multiple antimicrobial resistant strains of E. coli in Egyptian meat products may constitute high potential risk for consumers in the absence of strict hygienic and preventative measures to avoid the presence of resistant bacterial isolates and enterotoxin production in foods. The presence of multidrug resistant isolates causes alarm and underlines the necessity as to a careful choice and a cautious use of antibiotics in E. coli treatment.

The use of innovative techniques for the identification of the genes coding for the production of enterotoxin would enable the identification of strains that carry genes that might in suitable conditions produce as yet unknown toxins potentially capable of producing sickness in humans.

\section{Conflict of Interest}

There is no conflict of interest.

\section{Acknowledgements}

All thanks and appreciations to staff in the laboratory of Food Hygiene and Control Department, Faculty of Veterinary Medicine, Mansoura University, wherein the bacterial isolation were done in this study.

\section{References}

[1] Olaoye, O.A. and Onilude, A.A. (2010) Investigation on the Potential Use of Biological Agents in the Extension of Fresh Beef in Nigeria. World Journal of Microbiology and Biotechnology, 26, 1445-1454. http://dx.doi.org/10.1007/s11274-010-0319-5

[2] Lambert, A.D., Smith, J.P. and Dodds, K.L. (1991) Shelf Life Extension and Microbiological Safety of Fresh Meat-A Review. Food Microbiology, 8, 267-297. http://dx.doi.org/10.1016/S0740-0020(05)80002-4

[3] Olaoye, O.A. (2011) Meat: An Overview of Its Composition, Biochemical Changes and Associated Microbial Agents. International Food Research Journal, 18, 877-885.

[4] Selander, R.K., Musser, J.M., Caugant, D.A., Gilmour, M.N. and Whittam, T.S. (1987) Population Genetics of Pathogenic Bacteria. Microbial Pathogenesis, 3, 1-7. http://dx.doi.org/10.1016/0882-4010(87)90032-5

[5] Wieler, L.H., Ilieff, A., Herbst, W., Bauer, C., Vieler, E. and Bauerfeind, R. (2001) Prevalence of Enteropathogens in Suckling and Weaned Piglets with Diarrhea in Southern Germany. Journal of Veterinary Medicine, 48, 151-159. http://dx.doi.org/10.1046/j.1439-0450.2001.00431.x

[6] Dobrindt, U., Hentschel, U., Kaper, J.B. and Hacker, J. (2002) Genome Plasticity in Pathogenic and Nonpathogenic Enterobacteria. Current Tropical Microbiology and Immunology, 264, 157-175. http://dx.doi.org/10.1007/978-3-642-56031-6_9

[7] Laury, A., Echeverry, A. and Brashears, M. (2009) Fate of Escherichia coli O157:H7 in Meat. Chapter 2. In: Toldra, F., Ed., Safety of Meat and Processed Meat, Springer, Berlin, 31-53. http://dx.doi.org/10.1007/978-0-387-89026-5_2

[8] Novicki, T.J., Daly, J.A., Mottice, S.L. and Carroll, K.C. (2000) Comparison of Sorbitol MacConkey Agar and a Two-Step Method Which Utilizes Enzyme-Linked Immunosorbent Assay Toxin Testing and a Chromogenic Agar to Detect and Isolate Enterohemorrhagic Escherichia coli. Journal of Clinical Microbiology, 38, 547-551.

[9] Mohammed, M.A.M. (2012) Molecular Characterization of Diarrheagenic Escherichia coli Isolated from Meat Products Sold at Mansoura City, Egypt. Food Control, 25, 159-164. http://dx.doi.org/10.1016/j.foodcont.2011.10.026

[10] Ghosh, B., Sharda, R., Chhabra, D. and Sharma, V. (2003) Subclinical Bacterial Mastitis in Cows of Malwa Region of Madhya Pradesh. Indian Veterinary Journal, 80, 499-501.

[11] Van den Bogaard, A.E. and Stobberingh, E.E. (2000) Epidemiology of Resistance to Antibiotics. Links between Ani- 
mals and Humans. International Journal of Antimicrobial Agents, 14, 327-335. http://dx.doi.org/10.1016/S0924-8579(00)00145-X

[12] Barrow, G.I. and Feltham, R.K. (1993) Cowan and Stell’s Manual for Identification of Medical Bacteria. 3rd Edition, Cambridge University Press, Cambridge, 136-138. http://dx.doi.org/10.1017/CBO9780511527104

[13] CLSI (2011) Clinical and Laboratory Standards Institute. Performance Standards for Antimicrobial Susceptibility Testing, 21st Informational Supplement. CLSI Document M100-S21. Clinical and Laboratory Standards Institute, Wayne.

[14] El-Naggar, W., El-Sokkary, M.A., Barwa, R., Abd El Galil, K., Shokralla, S. and Abdel-Rhman, H.Sh. (2011) Phenotypic and Genotypic Characteristics in Relation to Some Efflux Pump Systems in Escherichia coli and Klebsiella pneumoniae Clinical Isolates. The Egyptian Journal of Medical Microbiology, 20, 1-14.

[15] Selvan, P., Narenda, R.B., Sureshkumar, S. and Venkataramanujam, V. (2007) Microbial Quality of Retail Meat Products Available in Chennai City. American Journal of Food Technology, 2, 55-59. http://dx.doi.org/10.3923/ajft.2007.55.59

[16] Pesavento, G., Ducci, B., Comodo, N. and Nostro, A.L. (2007) Antimicrobial Resistance Profile of Staphylococcus aureus Isolated from Raw Meat: A Research for Methicillin Resistant Staphylococcus aureus (MRSA). Food Control, 18, 196-200. http://dx.doi.org/10.1016/j.foodcont.2005.09.013

[17] Adekunle, O., Coker, A. and Kolawole, D. (2009) Antibiotic Susceptibility Pattern of Strains of Campylobacter coli Isolated in Osogbo, Nigeria. Biology and Medicine, 1, 20-23.

[18] Zhao, L., Chen, X., Zhu, X., Yang, W., Dong, L., Xu, X., Gao, S. and Liu, X. (2009) Prevalence of Virulence Factors and Antimicrobial Resistance of Uropathogenic Escherichia coli in Jiangsu Province (China). Urology, 74, 702-707. http://dx.doi.org/10.1016/j.urology.2009.01.042

[19] Motina, E. and Yadava, R. (2005) Antimicrobial Sensitivity of Escherichia coli Isolated from Fish. Indian Veterinary Medical Journal, 29, 68-70.

[20] Álvarez-Fernández, E., Cancelo, A., Díaz-Vega, C., Capita, R. and Alonso-Calleja, C. (2013) Antimicrobial Resistance in E. coli Isolates from Conventionally and Organically Reared Poultry: A Comparison of Agar Disc Diffusion and Sensi Test Gram-Negative Methods. Food Control, 30, 227-234. http://dx.doi.org/10.1016/j.foodcont.2012.06.005

[21] Yadav, M.M., Roy, R., Sharda, R. and Arya, A. (2007) Detection of Toxin Genes and Antibiogram Pattern in E. coli Isolates from Sheep Meat on Indian Market. Veterinarski Arhiv, 77, 485-494.

[22] Suojala, L., Pohjanvirta, T., Simojoki, H., Myllyniemi, A., Pitka, A., Pelkonen, S. and Pyo, S. (2011) Phylogeny, Virulence Factors and Antimicrobial Susceptibility of Escherichia coli Isolated in Clinical Bovine Mastitis. Veterinary Microbiology, 147, 383-388. http://dx.doi.org/10.1016/j.vetmic.2010.07.011

[23] Van, T.H., Chin, J., Chapman, T., Tran, L.T. and Coloe, P.J. (2008) Safety of Raw Meat and Shellfish in Vietnam: An Analysis of Escherichia coli Isolations for Antibiotic Resistance and Virulence Genes. International Journal of Food Microbiology, 124, 217-223. http://dx.doi.org/10.1016/j.ijfoodmicro.2008.03.029

[24] Wagner, S., Gally, D. and Argyle, S. (2014) Multidrug-Resistant Escherichia coli from Canine Urinary Tract Infections Tend to Have Commensal Phylotypes, Lower Prevalence of Virulence Determinants and ampC-Replicons. Veterinary Microbiology, 169, 171-178. http://dx.doi.org/10.1016/j.vetmic.2014.01.003

[25] Ezekiel, C.N., Olarinmoye, A.O., Oyinloye, J.M.A., Olaoye, O.B. and Edu, A.O. (2011) Distribution, Antibiogram and Multidrug Resistance in Enterobacteriaceae from Commercial Poultry Feeds in Nigeria. African Journal of Microbiology Research, 5, 294-301.

[26] Esimone, C.O., Nworu, C.S. and Harrison, G.T. (2010) Antibiogram and Plasmid Profile of Some Multi-Antibiotics Resistant Urinopathogens Obtained from Local Communities in Southeastern Nigeria. Ibnosina Journal of Medicine and Biomedical Sciences, 2, 152-159.

[27] Tompkins, L. (1985) DNA Methods in Clinical Microbiology. In: Lamette, E.H., Balows, A., Hauser Jr., W.J. and Shadomy, H.J., Eds., Manual of Clinical Microbiology, 4th Edition, American Society for Microbiology, Washington DC, 1023-1028.

[28] Sousa, C.P. and Dubreuil, J.D. (2001) Distribution and Expression of the astA Gene (EAST1 Toxin) in Escherichia coli and Salmonella. International Journal of Medical Microbiology, 291, 15-20. http://dx.doi.org/10.1078/1438-4221-00097

[29] Zahfer, H.J.A. (2013) Studies on Enterotoxins of Escherichia coli Strains Isolated from Various Sources. Master Thesis, Mansoura University, Mansoura.

[30] Vu Khac, H., Holoda, E., Pilipcinec, E., Blanco, M., Blanco, J.E., Mora, A., Dahbi, G., López, C., González, E.A. and Blanco, J. (2006) Serotypes, Virulence Genes, and PFGE Profiles of Escherichia coli Isolated from Pigs with Postweaning Diarrhoea in Slovakia. BMC Veterinary Research, 20, 2-10. 
[31] Shabana, L.L., Zaraket, H. and Suzuki, H. (2013) Molecular Studies on Diarrhea-Associated Escherichia coli Isolated from Humans and Animals in Egypt. Veterinary Microbiology, 167, 532-539. http://dx.doi.org/10.1016/j.vetmic.2013.08.014

[32] Mohammed, M.A., Sallam, K., Eldaly, E.A., Ahdy, A.M. and Tamura, T. (2014) Occurrence, Serotypes and Virulence Genes of Non-O157 Shiga Toxin Producing Escherichia coli in Fresh Beef, Ground Beef, and Beef Burger. Food Control, 37, 182-187. http://dx.doi.org/10.1016/j.foodcont.2013.09.035

[33] Gallien, P., Much, C., Perlberg, K.W. and Protz, D. (1999) Subtypisierung von stx-Genen in Shiga toxin-produzierenden Escherichia coli (STEC): Vorkommen in rohen Lebensmitteln und Korrelationen zu anderen Faktoren. Fleischwirtschaft, 79, 99-103. 